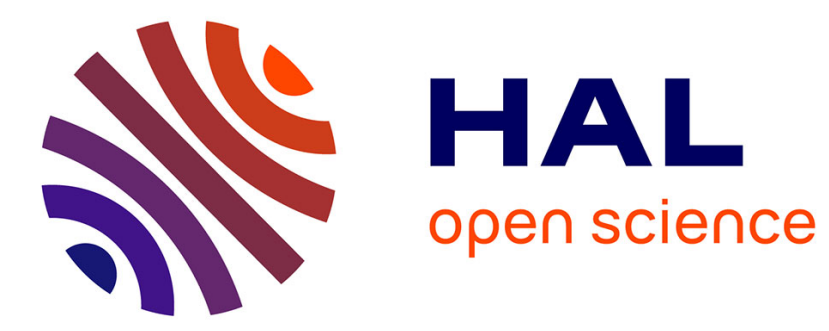

\title{
A 'little world of your own': stigma, gender and narratives of venereal disease contact tracing
}

\author{
Antje Kampf
}

\section{To cite this version:}

Antje Kampf. A 'little world of your own': stigma, gender and narratives of venereal disease contact tracing. Health, 2008, 12 (2), pp.233-250. 10.1177/1363459307086845 . hal-00571443

\section{HAL Id: hal-00571443 \\ https://hal.science/hal-00571443}

Submitted on 1 Mar 2011

HAL is a multi-disciplinary open access archive for the deposit and dissemination of scientific research documents, whether they are published or not. The documents may come from teaching and research institutions in France or abroad, or from public or private research centers.
L'archive ouverte pluridisciplinaire HAL, est destinée au dépôt et à la diffusion de documents scientifiques de niveau recherche, publiés ou non, émanant des établissements d'enseignement et de recherche français ou étrangers, des laboratoires publics ou privés. 


\title{
A 'little world of your own': stigma, gender and narratives of venereal disease contact tracing $^{1}$
} Vol 12(2): 233-250

\author{
Antje Kampf \\ Johannes Gutenberg-University Mainz, Germany
}

\begin{abstract}
A B STRACT As in other countries, in order to protect the public from venereal disease (syphilis and gonorrhoea), contact tracing in New Zealand has been a public health strategy since the mid-20th century. So far, scholars have predominantly focused on the aspect of control of the cases traced. Based on a rare interview with a female contact tracer, together with a range of archival material, this article aims to expand the scholarship by focusing on the tracer instead of the patient. Using Erving Goffman's original concept of 'courtesy stigma', the article will show that his idea can be nuanced to take into account contact tracers and the ways in which this stigma can be refracted through gender. Working as a tracer had a distinct impact on her life and possibly even her marital status, which were compromised by secrecy, stigma, morality and the demands of public health policies - aspects that were, paradoxically, quite similar to those she traced. The courtesy stigma that contact tracers for venereal disease acquired limited their professional options, as well as isolated them in the non-stigmatized social world.
\end{abstract}

K E Y W O R D S contact tracing; gender; New Zealand; stigma; venereal disease

ADd REs S Prof. Antje Kampf, PhD (Auckland), MA (Cincinnati), Junior Professor for the History, Philosophy, Theory and Ethics of Medicine (Gender Aspects), Institute for the History, Philosophy, Theory and Ethics of Medicine, Johannes Gutenberg-University Mainz, Am Pulverturm 13, D-55131 Mainz, Germany. [Tel:+49(0)61313933401;fax:+49(0)61313936682; e-mail: antje.kampf@uni-mainz.de]

ACKNOWLEDGEMENT An earlier version of this article was read at the June 2005 conference of the West of England and South Wales Women's History Network held in Bristol, England. I would like to thank Katherine Holden and participants for their help and assistance. I am indebted to the interviewees for sharing their experience and memories with me. Thanks to the New Zealand Ministry of Health, Crown Public Health and the Canterbury District Health Board for granting me access to their files. 
Many thanks to Aaron Fox, Gabrielle Fortune and Sara Buttsworth for their insightful comments and suggestions, and Belinda Rule for her impeccable editorial help.

A recent assessment of the experience of nurses working in Sexual Health Services in New Zealand in 2003 identified a 'psychological impact of negative social attitudes', not only on 'the people who visit sexual health services' but also on 'the staff who work there' (White and Mortensen, 2003). Working with a range of sexually transmitted diseases, it was found that sexual health nurses came to be associated "with the "dirty" aspects of sexuality' (White and Mortensen, 2003). This is not, however, a recent problem. These nurses were standing at the culmination of a social trend that has impacted on public health nurses for decades. Some 30 years earlier, public health nurses went outside the clinic to search for the sexual contacts of infected patients, and to track down patients who missed their treatment appointments. These so-called 'contact tracers' were subject to a similar stigma to that of the sexual health nurses in 2003. Contact tracer 'Marsha' (pseudonym), a New Zealand Department of Health public health nurse, and from the 1970s to the mid-1980s a contact tracer for venereal disease (gonorrhoea and syphilis), was known by the police, the local Department of Health and at the venereal disease clinic, but when interviewed she maintained that her life was 'a little world of your own because you can't talk to anybody about it'. ${ }^{2}$

In his classic study on social stigma and illness, Erving Goffman (1990) drew attention to the 'spoiled identities' of stigmatized people suffering from mental disorders or disabilities. They were not alone in experiencing stigma, Goffman (1990: 43-4) argued, as those associated with stigmatized people also had to face social degradation - a condition he called 'courtesy stigma'. ${ }^{3}$ Family members or friends of those struck with a disease or condition that was connected with negative social attitudes had to live in two realities: in the world of the non-stigmatized, and in the social world of the stigmatized. Goffman's theory has remained important to sociologists, who have discussed the impact of stigma predominantly on families and friends (Alonzo and Reynolds, 1995). However, few have applied this idea to health care providers (Durham, 1994). I will use the concept of courtesy stigma for this historical account of the experience of contact tracers of venereal disease, extending Goffman's idea and arguing that health care providers are also stigmatized because of their association with stigmatized patients and (in the case of contact tracers) their connection with promiscuity and illicit behaviour. This article emphasizes that the stigma extended to those apparently in control of stigmatized persons, the contact tracers. In response to even the possibility of being ostracized, contract tracers withdrew themselves from parts of society voluntarily, as well as being excluded by their work.

There is a gender component here that needs to be explored, as there is a history of association between women and venereal disease, from the 
Contagious Diseases Acts of the 19th century onwards, particularly during both world wars, in Britain and New Zealand. Fear of venereal disease has been used as an excuse to regulate and intrude on women's lives, more than has been the case for men (Brandt, 1987: 161-74; Dux, 2001: 47-64; Fleming, 1989: 94-7, 177-81; Gilman, 1988: 245-312; Hall, 2001: 132; Jarvis, 2004: 79-84; Lemar, 2001: 144-7; Mooij, 1998: 139-42; Sturma, 1988: 725-40). What is specifically gendered about the profession and its associated stigma is that the majority of contact tracers were female, as were the majority of cases traced, while informants and doctors were predominantly male. As promiscuity and illicit sexual behaviour were connected to marital status, singleness was seen as an increased risk factor for acquiring venereal disease. To be single and to be female meant to be tainted and stereotyped. The original idea of a courtesy stigma, however, is not a specifically gendered concept. Recently, scholars have used the category of gender to refine an analysis of courtesy stigma for families and friends, but so far, little has been written on health care providers. This article will show that the concept of courtesy stigma can be nuanced to take into account contact tracers and the ways in which this stigma can be refracted through gender.

Despite the considerable number of scholars working in the area of the history of venereal disease, and on traced patients and their control, little has been written specifically on the contact tracers themselves (Davidson, 1996; Smith, 1996). A major reason for this gap in our knowledge is the scarcity of sources on contact tracers. Contact tracing and venereal disease infection have always been a sensitive matter. Thus, detailed information in health files is often missing. Specifically, for the second half of the 20th century, access to patient files has been restricted due to confidentiality issues and privacy legislation. In New Zealand this situation is further complicated, as the number of contact tracers for venereal disease remained very small throughout the 20th century, meaning there was little organizational structure to their profession. In addition, it is possible institutional knowledge about disease surveillance and the contact tracing function was lost with the merger of the Department of Health and Hospital Boards in the 1980s. ${ }^{4}$

So, how can we gain understanding of the role of tracers? Oral testimony has been a useful method of revealing the lives of those who are missing from official histories. It is a method used particularly in Women's History, which has often found a tradition of female silence in other sources, and also valued in medical history for its ability to recapture patient voices (Davies, 2001; Geiger, 1992; Morantz et al., 1985). Tracking down New Zealand contact tracers has proved to be very difficult, which made the opportunity to interview Marsha in her capacity as a contact tracer special indeed. ${ }^{5}$ Now in her 80 s, it was the first time she had told someone outside of her profession about her work in the decades after the Second World War. There is an irony in continuing to conceal Marsha's identity by using a pseudonym; however, this is necessary to protect the privacy of the interviewee. My theoretical approach in terms of women's narratives has been informed 
by Chilla Bulbeck's method of dealing with women's oral histories, and a feminist ethics of dealing with the material and process of interviewing. While I do not adopt her self-consciously feminist stance, I parallel Bulbeck's effort to use interviews for an 'understanding of the meaning people ascribe to their lives' (Bulbeck, 1997: 6). I use thematic interviews to attempt to recapture the work of the contact tracer. This article uses this oral testimony in addition to the only other - to my knowledge - published interview of a New Zealand contact tracer during the Second World War. Taking a qualitative approach, this article places both accounts in context with interviews of health officials, partly unpublished archival material from the Department of Health and clinic reports. These further contextual sources are not supplementary material, but are used with the interviews for mutual illumination, each providing information and supplying new lines of inquiry for each other. This article cannot claim to provide a universal account of the contact tracer's role, but it can elucidate whether the experiences of the two tracers in question were an indicative example of a contact tracer's role, or constituted unique experiences (Singer, 1997: 1-33).

\section{Development of contact tracing}

As in other countries, there was a slow shift of emphasis in public health, originating in the late 19th century. A focus on the need to clean up the urban social environment was gradually replaced by an interest in the responsibility of the individual in preventing infectious diseases. Notification, examination and treatment became the main tools of infectious disease control in the 20th century (Dow, 1995: 73-8; Porter, 1999: 165). Female nurses had a specific role in this process, of bridging and networking between patients, doctors and the State. With only part-time venereologists available, of whom the majority were male, nurses occupied a larger role than usual in frontline dealings with patients and follow-up of treatment. ${ }^{6}$ As nurses, they were more invested in this aspect of health care; yet the tracers' own patient focus did not by itself influence health policy to become more patient-focused that was left to Health Department officials and venereologists. Since the mid-20th century, following international trends (Davidson, 1996: 195-8; Lemar, 2001: 151-5; Wollacott, 1994), contact tracing has been a major public health strategy of the New Zealand Department of Health, used to protect the public from venereal disease and control outbreaks or further propagation.

The precursors of contact tracers in New Zealand were the so-called 'health patrols', which in order to 'protect the health and morality of young persons', were officially introduced with the 1917 Social Hygiene Act. This Act also established venereal disease clinics around the country, and stipulated for the first time that an infected person was obliged to seek treatment (New Zealand Statutes, 1917, clause 12: 3-5). These public health measures were deemed necessary due to concerns about the health 
of returned servicemen, and about the increasing numbers of mainly young single women who were coming to urban areas in search of work and - it was feared by welfare groups, the Department of Health and doctors - of extra-marital affairs, which would lead among other ills to venereal disease infection. This action to curb an expected increase in venereal disease infection in the population was further influenced - as in other countries - by fears for national efficiency, as the majority of those infected were in the prime of their lives, and by fears for maternal and infant health (particularly with syphilis infection) (Bryder, 2003; Porter, 1999: 166-82, 186-90).

By contrast to other infectious diseases such as pulmonary tuberculosis and AIDS, gonorrhoea and syphilis were not compulsorily notifiable throughout the 20th century. Thus, the health patrols were not originally intended to trace people already identified by the Department as infectious, but instead were to target individuals of both sexes who were not chaperoned in public places, and in whom infection might be identified and treated at the clinics. There were unfulfilled suggestions, such as those by the YWCA, also to use the women patrols to encourage men away from the path of immorality (Coney, 1986: 92). The health patrols were comprised of women only, a policy similar to that adopted for tuberculosis control measures, where the Department preferred the use of women due to allegedly better efficiency (Bryder, 1991: 120). The patrols turned their attention to the young, single females who were increasingly visible on the streets, and to children living in unhygienic conditions, which was believed to make them vulnerable to contracting venereal diseases (New Zealand Gazette, 1918: 2823).

Due to controversy over their alleged emphasis on moral rather than health matters, the Department disbanded the patrols by $1922 .{ }^{7}$ The apparent public health need to control venereal disease did not abate, as by 1925 the Social Hygiene Regulations introduced conditional notification, requiring doctors to notify the Department of patients missing from treatment for longer than two weeks, and calling for health inspector nurses to search out these 'defaulters'. Yet lack of staff and financial resources circumscribed the outcomes of these initiatives. Until the Second World War, female nurses at the clinics only occasionally, and in an unofficial capacity, followed up cases.

During the Second World War, a perceived threat of increased venereal disease in wartime, and the presence of American servicemen in New Zealand - of whom alone in June 1942, 17,000 came to New Zealand shores (Baker, 1965: 73) - prompted health officials to make contract tracing a priority in disease prevention once more. ${ }^{8}$ Statistics seemed to justify these fears, as female attendance for syphilis and gonorrhoea per annum at the clinics nearly doubled between 1939 and 1942 (AJHR, 1945: 3; Mercer, 1941: 343-4). It was not established whether this increase in clinic attendance indicated a real increase in incidence of disease. The statistics related to clinic attendance only, and thus reflected the absence of men due to the 
Services, and also failed to reflect that many (married) middle-class females went to a general practitioner privately, of which we have scarcely any statistics. Nevertheless these numbers fed into the debate by the police and welfare groups about the sexual morality of young, single women who came to towns (Montgomerie, 1989) and were often regarded as 'the primemovers in proposing sexual inter-course', and the origin of infection. ${ }^{9}$ The 1941 Venereal Disease Regulations established the first official contact tracers for venereal disease, four years later than in England. They were to trace defaulters as well as suspected cases (Thin, 1984: 269-72). Most often these contacts came from male patients at the clinics who informed of their female contact. The number of contact tracers, however, was small. Sources document only three female nurses being employed, one each for Wellington, Auckland and Christchurch.

Dwindling venereal disease numbers after the Second World War resulted in the deprioritization of contact tracing. Then, in the mid-1960s, venereologists were alerted to an upsurge in venereal disease rates, related mainly to changes in the sexual behaviour of the young (associated with rising illegitimacy rates), and a persistent lack of notification by clinics and doctors. ${ }^{10}$ Legislative changes in 1964, however, left the notification procedures as they were, as the medical profession and most Medical Officers of Health (MOHs) feared 'possible ethical and legal implication' if stricter notification were instituted. ${ }^{11}$ They maintained it would drive infection underground, endanger patient-doctor relationships and compromise patients' rights (Platts, 1964: 83). ${ }^{12}$ Yet the venereologists' call for the attachment of professional contact tracers to all clinics gained ground only slowly. ${ }^{13}$ The employment of these contract tracers was subsequently instituted under the old Regulations - the first full-time public health nurse for contact tracing began work in 1974 at the Auckland Venereal Disease Clinic - but in an uncoordinated fashion and by the initiative of local hospital boards only. Venereologists seem to have preferred female workers 'as they get better results' ${ }^{14}$ Here, the narratives of contact tracing were gendered: the 'feminine' traits of social networking and involvement in the community seemed to be obvious in female contact tracers, who followed up more cases and were seen to be more caring.

There was a change to contact tracing in the post-war years, with the addition of international tracing and chain tracing to the list of contact tracers' tasks. Chain tracing was the idea of finding not only the immediate contact, but also any subsequent contacts. This modification in contact tracing strategy reflected a change in belief about the cause of venereal disease. At the times of health patrols, venereal disease was thought to be predominantly connected with the immorality of the prostitute or 'amateur', and later also that of the wayward husband. It was a matter of finding the one sexual contact. Now there was a change in focus, as the understanding was that at least three people were involved. ${ }^{15}$ Venereal disease was considered to be connected to promiscuity and individual sexual behaviour, and the group of people to be investigated was expanded. Contact tracers 
such as Marsha were to find 'friends, acquaintances or relatives of cases who had similar behaviour patterns, and who were likely to be infected' (Bierre, 1973: 383).

By the mid-1970s contact tracing was considered 'almost more important than the actual treatment', illustrating the growing emphasis on personal behaviour and prevention at a time when the availability of drugs, which could cure venereal disease infection (penicillin and sulfa drugs), increased personal risk-taking. ${ }^{16}$ At the same time, the Department introduced 'contact slips' at the clinics with a code for diagnosis, and a patient's number only, so that the patient was able to pass the slip on to his or her sex partner, saving patients 'the need for embarrassing explanations'. ${ }^{17}$ This so-called partner notification in many clinics subsequently supplanted contact tracers' tasks.

\section{The contact tracers' role}

The contact tracers' tasks were defined as: finding contacts; handing out the Departmental forms; and bringing contacts to the clinics if necessary. The outcome of their work was treatment, and only in a very few cases prosecution. This work, however, entailed a much wider commitment. A tracer's role combined those of a public health nurse, a social worker and a kind of detective in one person. This role developed in an erratic fashion, it was uncoordinated and it existed under a cloud of secrecy.

The education and training of contact tracers remained piecemeal and inadequate, indicating the low status of the profession. There was a lack of professional development for the nurses. The contact tracers who were officially introduced in 1941 were trained public health nurses, but they did not receive medical training on venereal disease or manuals on tracing, except for a list of the current laws and regulations. The pay for their work was insufficient. It took three years after their initial appointment to provide contact tracers with the pamphlet 'Plain words: A guide to sex education', yet even this pamphlet most likely did not include information on venereal disease. ${ }^{18}$ Wellington's contact tracer, Margaret Macnab, remembered her training had nothing 'to do with social hygiene, with people who were suffering from social diseases' (Macnab, 1989: 30). This lack of information parallels the lack of information given to servicewomen during the Second World War: it was feared that knowledge of venereal disease would somehow contaminate and corrupt women - in contrast to servicemen who were quite graphically informed. This pattern in gendered information provision continued.

The post-Second World War role of a contact tracer more closely resembled that of a social worker, with venereologists expecting her to help with 'Rehabilitation in family living, health education and personal advice in prevention'; in short to offer a 'community service'. ${ }^{19}$ Yet initiatives to send tracers to the United States for training in social work and contact tracing were halted for financial reasons. ${ }^{20}$ By 1971, still only 10 per cent 
had professional training. ${ }^{21}$ Marsha recalled being very much left to her own devices in tracking contacts, and that her success was due to her initiative and 'detective work' ${ }^{22}$ Official sex or venereal disease education was by the 1970s still in its infancy: before the late 1970s there were no New Zealand Departmental booklets on venereal disease, and the Departmental sex education booklets since 1964 contained only very general information. Marsha used an American comic-style book for educating teenagers, and on her own initiative occasionally gave talks at youth prisons and high schools, offering personal advice, as well as talks to doctors about how they could help with information provision. ${ }^{23}$ In short, contact tracers' work was sidelined, at least from a professional point of view.

The lack of informational material and training was coupled with a lack of authority to enforce their positions, at least for female tracers, although they could engage the police when patients resisted coming to a clinic or doctors' rooms for examination and treatment. Occasionally they had to ask for police protection but, in contrast to their male colleagues, for a time they had no warrants to legitimize their position to the police - a situation only changed after complaints from the contact tracers. ${ }^{24}$ This problem reoccurred in the 1960s, a situation not eased by a Departmental policy that saw tracers working in civilian clothes and using private rather than government cars. ${ }^{25}$

A major responsibility of a contact tracer was to protect the identity of informants and secure patient privacy; only the Department, medical practitioners and the police were to know of the persons with whom they had their appointments (Macnab, 1989: 35). As already noted, tracers did not wear their nursing uniforms or drive a government car. Confidentiality, as Marsha acknowledged, was the main requirement for success: it was '110 per cent important that they can trust you'. ${ }^{26}$ Yet contact tracing was frequently handicapped by insufficient information, forcing tracers to use street descriptions or physical features (Macnab, 1989: 30). These descriptions could be useless, such as 'she goes to the hotel at Friday nights and she drinks Southern Comforts', or cheeky, as in, 'Kathleen - with a generous superstructure'. ${ }^{27}$ Wrong or out-of-date addresses gave contact tracers a tiring and often unsuccessful hunt around town. In 1944 one-third and 1945 more than one-half of the contacts in Wellington could not be located (Morgan, 1947: 90-1). With often insufficient or false data being provided, inevitably forms would be served to the wrong woman, causing much distress. Tracing reports for the 1940s and the 1970s reveal that of all notified venereal disease cases only half, in some cases only a quarter, ultimately proved to be infected. ${ }^{28}$ Macnab, for example, remembered with regret how in one instance the notified woman turned out to be a virgin, and the man a liar (Macnab, 1989: 38). By contrast, MOHs, who did not come into close contact with those traced, seemed to have been more worried about libel suits. ${ }^{29}$ They took a view similar to that espoused in the only officially endorsed venereal disease pamphlet at the time: that no harm 
was done by false notification except to the woman's 'self-esteem', a 'small price to pay for such a valuable means of tracing the source of infection' (Martyn, 1942: 23). The fear of defamation charges - as it was a libelous act to claim wrongfully that a person had venereal disease - was still expressed by the 1960s. William M. Platts, foremost venereologist in New Zealand in the post-war decades, warned in 1963 about the prospect of 'aggrieved female[s]' who 'may start thinking in terms of damages'..$^{30}$

It appears that confidentiality and secrecy limited the tracers' capacity for networking, and handicapped their personal and professional lives. At least until the first conference of contact tracers was convened in 1985, sources do not reveal any networking activities between contact tracers (Keane, 1986). ${ }^{31}$ Marsha, for example, did not know of her other colleagues. ${ }^{32}$ As she was unable to share confidential information, the work with nurses at the clinics was 'very difficult sometimes' ${ }^{33}$ There did not appear to be any advancement in professional status associated with their new role, and their work - though spearheading what could be called 'social work' - ended up contributing little to the general standing of nurses today. Instead, there was social exclusion in a professional sense.

The necessity to associate with places and persons of dubious repute contributed to the courtesy stigma and the ensuing social reclusion of contact tracers. Marsha's job, as that of the other tracers, was rough, difficult and often thankless. This 'underground work', for example, kept Marsha 'apart from my colleagues'; she was 'always working alone' and doing 'a lot of late night work ${ }^{34}$ To deliver Department forms, the tracers had to walk in unsafe places at night, and stay in bars or run-down boarding houses; they moved 'amongst promiscuous teenagers and seafarers; in taverns and amusement parlors ${ }^{35}$ Marsha also remembered situations that brought her close to the drug scene and gangs. ${ }^{36}$ Clearly, these duties were contra productive to establishing a marriage, family or much of a social life, particularly as the tracer was not allowed to speak to anybody of her work. Contact tracers were thus isolated, a feature usual to the experience of stigmatized people. Contact tracers' concealment, a work requirement as much as a tribute to the stigma of disease, transformed tracers into what Goffman has called a 'discreditable' person, by way of a 'differentness [that] is not immediately apparent' (1990: 57).

\section{Tracing contacts}

Contact tracing was a controlling strategy, directed towards turning aside the increase in venereal disease infection and in numbers of defaulting patients that was also occurring in America, Australia and Great Britain in the 20th century (Fairchild et al., 2003; Hall, 2001: 135-6; Lemar, 2001: 150-60). ${ }^{37}$ In New Zealand, health patrols were 'policing their own sex' in the early 1920s, and during the Second World War venereal disease sufferers were also subjected to greater control (Fleming, 1989: 197, 199). 
Contact tracers did use some coercion. Contact tracer Cameron's plea that her job was not of 'a "Police" nature' reveals she was aware of the double nature of her duties - to care for and control - a position exacerbated by the authority to engage the police if a person resisted.$^{38}$ Marsha also emphasized that word 'soon gets around. If you don't go you will be taken by police.' ${ }^{39}$

Yet contact tracers' control of patients, and tracing success, during the Second World War and in later decades, was often incomplete for various reasons, and it would be too easy to ascribe to contact tracers a purely policing role. Contact tracers' authority was sidelined when patients arrived, as many did, on the advice of their sex partners rather than as a result of the coercion of the tracer (Black and Farb, 1943: 34). This trend was supported by the Department, which insisted it preferred to have patients bring their contacts to clinics on their own initiative. ${ }^{40}$ Despite stringent regulations, the majority of patients went to private doctors or used selfmedication, escaping contact with the law, and thus control (Dallas and Rainey, 1948: 39). Health officials were too busy with other issues to act to stop this, and feared legal action if patients were wrongfully removed; and many doctors also continuously neglected notification. ${ }^{41}$ Arrests for failure to comply with notices served were negligible in the Second World War, as in later decades. In 1943, the police were called in 35 cases, constituting less than 1 per cent of venereal disease patients undergoing compulsory treatment at public clinics, at a time when national attendance figures were 1480 patients (AJHR, 1945: 3; Morgan, 1947: 90-1). Marsha, who served several hundred notices, had only six or seven persons arrested in her seven years of work - it was 'a very rare situation'. ${ }^{42}$ Although there was a conjunction with the medical profession, the Health Department and the police, contact tracers none the less worked predominantly by themselves and within the social worlds of those they traced.

There was also open resistance to contact tracers - confirming Judith Walkowitz's point that women still exercised agency despite being subjected to control by reformers and social workers, and were 'not innocent because they [were] on the sidelines [of power]' (1992: 9-10). At times contact tracers experienced violence, when traced persons proved not to appreciate their supervision. Contact tracers complained of a large population of transient persons who were difficult to find, and who were 'complete liars'. ${ }^{43}$ Patients often refused to give names or stated false addresses. While David Evans (2001: 241) found in the English context no proof of 'informal compulsion', sources for New Zealand suggest that at least some people felt cornered. Despite Macnab's (1989: 33) insistence that she never experienced 'any physical antagonism' towards herself, it seems unlikely that this did not happen. Tracers' work was dangerous at times, requiring fortitude and character. A Christchurch colleague listed in her report to the Nurse Inspector that she had had to pay 'Danger money. My life has been threatened twice. ${ }^{44}$ Marsha was hit while serving a notice, or threatened with harm. ${ }^{45}$ She was only allowed to interview male clients for contacts, not 
to trace them, as it was a 'safety thing for me as much as anything'. ${ }^{46}$ 'I got kicked, I got punched, I got physically assaulted many times. ${ }^{47}$

The tracers' role was somewhat contradictory. Although they were to reduce contact with the suspected infected woman to a minimum, and were expected not to involve themselves in the case emotionally, they were none the less to provide a community service that demanded a certain engagement. As Macnab insisted, she was not 'supposed to be concerned with these girls' morals at all ... my concern was to be purely a physical one. But it was very difficult sometimes not to be involved' (1989: 35).

It appears that contact tracers rather wanted to be seen as motherly figures for the often much younger women they worked to locate and assist. They extended their limited role as they saw fit, often out of genuine, if patronizing, concern. Their concern was about promiscuity or sexual morals, but more often about social conditions. Their work revealed to the Department that some living quarters of notified women were 'very far from perfect', resulting in inspection visits to hotels. ${ }^{48}$ Macnab (1989: 37, 41-2) remembered several instances where she cooked for prostitutes, and she cared for a desperate young mother. Nurse Instructor Flora Cameron recommended that in cases of non-attendance, contact tracers visited the women first instead of sending them a letter. She feared many were too ill to respond. ${ }^{49}$ Contact tracer Ramsay listed as tasks in her report: 'finding her a suitable home ... Finding employment for her ... Just listening to her story may take up to an hour, especially if she really loves him. ${ }^{50}$ Contact tracers often accompanied the women to the clinic (Morgan, 1947: 90-1), not only to ensure attendance but also for support. This seemed necessary, given that staff at the clinics apparently treated the women as 'outcasts', and 'had very little knowledge of social diseases and less sympathy with people who suffered from them' (Macnab, 1989: 37, 39). This stance was shared by Marsha nearly 30 years later: 'They have taken a mighty great step in even coming to this clinic. ${ }^{51}$ A mothering approach appeared again when Marsha turned the misfortune of being traced around, by telling the traced woman that 'the boy has done you a favour' by reporting, as she otherwise most likely would not have noticed the infection. ${ }^{52}$ Her colleague Ms M Ward spent much of her time 'in social help and psychological counselling, ${ }^{53}$ In this sense, contact tracers, after a period of sharing the same society as their stigmatized contacts, became part of their world.

Judgements about sex in relation to marital status have been important in the history of venereal disease. A concern for maternal and infant health was paramount to health officials, and that concern contained an underlying disapprobation of procreation outside marriage. In brief, it was the married ('innocent') who were believed to need protection from disease and from stigmatization, an understanding that was often shared by welfare groups, the Department of Health and doctors, in New Zealand and in other Commonwealth countries throughout the 20th century (Davidson, 2000: 237-58; Hall, 2000: 85-6; Lewis, 1997: 259-61). Times were set aside at 
clinics in the 1940s for 'married women and innocent people and children'. ${ }^{54}$ The 1956 Health Act, section 89, warned specifically 'against contracting any marriage' while infected. Stereotypes were perpetuated in the 1970s, when contacts were still divided into 'innocent' (married) and 'others' (unmarried) (Bierre, 1973: 382). Contact slips were designed for tracing 'secondary contacts, such as wives, fiancées and friends ... where considerable delicacy is required'. ${ }^{55}$ For venereologists, treating the married was 'a very delicate situation' and had to be handled 'extremely carefully'. ${ }^{56}$ Delicacy, it seems, was unnecessary for those outside the specified categories - single persons who engaged in casual sex apparently did not merit concern.

Single women were predominantly blamed for what was thought to be their promiscuity and propensity to transmit venereal disease. Their sexuality was stigmatized. Unmarried women were a social target in New Zealand as in other countries (Alexander, 1995; Kunzel, 1993). Medical Officer Jepson asserted in 1963, 'The main reservoir of infection is in young girls. ${ }^{57}$ The view of venereal disease as not simply a biological entity but also a social disease resulted in married women preferring private doctors, who often did not notify of defaulters. The few statistics incorporating marital status suggest that it was mainly the single person who visited the clinics and who was traced. ${ }^{58}$ In this context, contact tracers' work - with its long nights, visits to unsafe places (bars, brothels and gang headquarters) and dealings with stigmatized diseases and stigmatized people - was not conducive to marriage and family life. Indeed, 'husbands would want answers - where are you going? Why? ${ }^{59}$ To become a social recluse was a pre-emptive response to even the possibility of being cast out. There was no official policy that contact tracers were to remain unmarried, and sources remain silent on the marital status of the tracers, but as Marsha put it: 'It was better that we weren't married', a persuasion that kept her, at least, single all her life. ${ }^{60}$

\section{Conclusion}

When asked about his long-term experience as a venereologist, Dr Kelvin Bremner was adamant that by the 1970 s venereal disease was still considered shameful, and infected people 'dirty', and these perceptions rubbed off on doctors who treated it, who were looked down upon socially and medically. ${ }^{61}$ The same appears to be true of contact tracers, who came in touch with these 'spoiled identities', in turn rendering them equally isolated. This article suggests that the history of sexual health policy should incorporate the understanding that working as a contact tracer for venereal disease had a distinct impact on a tracer's social life. Tracers' lives were compromised by secrecy, stigma, morality and the demands of public health policy. The courtesy stigma that contact tracers for venereal disease acquired limited their options, as well as isolating them in the non-stigmatized social world. In this, paradoxically, the tracer had a great deal in common with 
those she traced, as she had to 'suffer many of the standard deprivations' of the courtesy group (Goffman, 1990: 44).

The gendered component should also to be stressed. Tracers often seemed to make sense of their mediating role - which demanded at the same time distance from and social engagement with those traced - by taking a motherly approach. Because the tracer shared the world of the stigmatized to an extent, singleness might have been a personal choice, but the work of the tracer made other options very difficult. Tracers' self-imposed social isolation and exclusion from certain aspects of society was also a result of their work. The role of the contact tracer ultimately did not contribute to the advancement of women in the health care system. Their work was too much a secret and too much associated with shunned diseases to provide a building block to further the professional status of health nurses today. Rather, their role reflected more clearly the traditional female roles in public health.

Goffman noted that stigma, or a tainted social label, changes the way individuals view themselves (and are viewed by others). Marsha, contemplating what it had meant for her to be a contact tracer, was unsure: 'I sometimes wonder if I was chosen for the job because I was a loner or if it was the other way around. ${ }^{62}$

\section{Notes}

1. This article is based in part on portions adapted from Kampf (2007). Venereal disease is the contemporary term and will be used in this article.

2. Interview with 'Marsha' (pseudonym), 13 April 2002.

3. On the reception of his concept, see Link and Phelan (2001).

4. Thanks to Peter Huggard for pointing this out to me.

5. The interviews passed through the ethics procedure of the University of Auckland Human Subject Ethics Committee.

6. Interview with Peter Huggard, 4 November 2003.

7. 'Letter, Herbert Chesson to Thomas Valentine (Director General of Health), 17 October 1919', New Zealand Department of Health H1 series (hereafter H1), 45/3, Archives New Zealand/Te Rua Mahara o te Kâwanatanga, Wellington Office (hereafter ANZW), New Zealand.

8. 'Letter, Michael Watt (Director General of Health) to Arnold Nordmeyer (Minister of Health), 12 November 1941', Venereal disease general 1939-41, H1 45 (B13), ANZW.

9. 'Medical Services Circular Memo No. 1, 21 June 1943', Army Department (hereafter AD1), 330/9/1, ANZW; 'Letter, New Women's Club to Nordmeyer, 7 May 1943', Venereal disease general 1942-57, H1 131/45 (23441), ANZW; 'Letter, Soroptimist Club of Wellington to Mary Lambie (Director Nursing Division), 28 September 1942', H1 131/45 (23441).

10. North Canterbury Hospital Board, 'Sexually Transmitted Diseases Questionnaire' (n.d. [1976]), Venereal disease correspondence and conferences 1973-6, CH588 14/6, ANZCH.

11. 'Précis of New Zealand law on venereal disease with certain proposals', Venereal disease general 1962-5, H1 131/45 (30312), ANZW. 
12. 'Minutes of the Conference on Venereal Disease 29 October 1965', Venereal disease Napier 1949-70, New Zealand Department of Health H-NA series (hereafter H-NA) 593, ANZW; Medical Officer of Health F. de Hamel to Turbott, September 1964, H1 131/45 (30312).

13. 'Proceedings Venereal Diseases Conference July 5, 1968', New Zealand Medical Journal (1968), 68(438), 327. 'Minutes of the National Conference on Venereology, 25-26 September 1974', Venereal disease correspondence and conferences 1973-6, Healthlink CH 588 (hereafter CH 588), 14/6, Archives New Zealand/Te Rua Mahara o te Kâwanatanga, Christchurch Office (hereafter ANZCH), New Zealand.

14. 'Minutes of the National Conference on Venereology, 20 October 1971', Venereal disease correspondence and general matters 1970-3, CH588 14/6, ANZCH.

15. Interview with Brigadier Brian McMahon, 7 December 2001. (McMahon worked as part-time venereologist in several hospitals, including military hospitals, around New Zealand from 1953 to 1968. He remained in the field, managing the STD services in the military after 1968.)

16. 'Minutes of the National Conference on Venereology, 20 October 1971', Venereal disease correspondence and general matters 1970-3, CH588 14/6.

17. 'The public health nurse and contact tracing in the Venereal Diseases Unit at Auckland Hospital', in 'Draft Agenda for the Eighth National Venereologists' Conference, 17 September 1972', Venereal disease correspondence and general matters 1970-3, CH588 14/6.

18. 'Letter, Librarian Health Department to Postgraduate Nurses' School, 12 October 1944', Sex hygiene 1939-55, H1 35/14 (25845), ANZW.

19. 'Letter MOH Jepson to Kennedy, 16 December 1971', Venereal disease correspondence and general matters 1970-3, CH588 14/6; North Canterbury Hospital Board, 'Sexually Transmitted Diseases Questionnaire' (n.d. [1976]), Venereal disease correspondence and conferences 1973-6, CH588 14/6.

20. 'Minutes of the National Venereologists' Conference, 21 September 1972', Venereal disease correspondence and general matters 1970-3, CH588 14/6.

21. 'Minutes of the National Venereologists' Conference, 21 September 1972', Venereal disease correspondence and general matters 1970-3, CH588 14/6.

22. Interview with 'Marsha' (pseudonym), 13 April 2002.

23. Interview with 'Marsha' (pseudonym), 13 April 2002; 'Marsha' (pseudonym), written correspondence with the author, 16 May 2006 (private possession).

24. 'Letter Hubert Smith to Watt, 27 May 1942', Venereal disease general 194257, H1 131/45 (23441), ANZW.

25. 'Marsha' (pseudonym), written correspondence with the author, 16 May 2006.

26. Interview with 'Marsha' (pseudonym), 13 April 2002.

27. Interview with 'Marsha' (pseudonym), 13 April 2002; Macnab (1989: 33).

28. 'V. D. Report 1st January 1943-31 December 1943', III Venereal disease general 1943-57, Department of Health, Auckland District Office BAAK series (hereafter BAAK), A358/143a, Archives New Zealand/Te Rua Mahara o te Kâwanatanga, Auckland Office (ANZAKL), New Zealand; 'The varied role of a contact tracer', New Zealand Society of Venereology Bulletin 1 (1979): 3 .

29. 'Letter, Hubert Smith to Colonel Kemp, 11 June 1942', H1 131/45 (23441); 'Letter, Greenslade to Watt, 3 April 1941', H1 45 (B13). 
30. 'Letter, Platts to Taylor, 28 November 1963', H1 131/45 (23441).

31. J.A. Keane (1986). 'To the Contact Tracers Conference at Futuna Wellington on the 3rd November 1986', typescript speech Contact Tracers Conferences, 3 November 1986, Wellington. (Private possession. I am grateful to Marie Prescott for the provision of this typescript.)

32. 'Marsha' (pseudonym), written correspondence with the author, 16 May 2006.

33. 'Marsha' (pseudonym), written correspondence with the author, 16 May 2006.

34. Holmes, 27; Interview with 'Marsha' (pseudonym), 13 April 2002; 'Marsha' (pseudonym), written correspondence with the author, 16 May 2006.

35. 'Napier Venereal Diseases Clinic Report 1973-74', in 'Minutes of the Tenth National Venereologists' Conference, 25-26 September 1974', Venereal disease correspondence and conferences 1973-6, CH588 14/6.

36. Interview with 'Marsha' (pseudonym), 13 April 2002.

37. See also Hall (2000).

38. 'Letter, Cameron to Watt, 2 October 1941', Health clinics - TB and VD 194144, H1 172/551, ANZW.

39. Interview with 'Marsha' (pseudonym), 13 April 2002.

40. 'Conference on Venereal Disease, 7 November 1939', Venereal disease general 1939-1943, BAAK A49/66b, ANZAKL; 'Letter, Cameron to Watt, 2 October 1941', H1 172/551.

41. 'Letter Hubert Smith to Watt, 9 July 1942', Venereal disease reports 1941-3, H1 45/47 (20361), ANZW; 'Circular letter to Superintendents of all Public Hospitals, 3 July 1942', H1 45/47 (20361).

42. Interview with 'Marsha' (pseudonym), 13 April 2002.

43. 'Wellington Report to Conference in Wellington 1972', in 'Minutes of the National Venereologists' Conference, 21 September 1972', Venereal disease correspondence and general matters 1970-3, CH588 14/6.

44. 'Letter, N.F. Ramsay to Miss Mann Nurse Inspector' (n.d.), H1 131/45 (30312).

45. Interview with 'Marsha' (pseudonym), 13 April 2002.

46. 'Marsha' (pseudonym), written correspondence with the author, 16 May 2006.

47. 'Marsha' (pseudonym), written correspondence with the author, 16 May 2006.

48. 'Letter, Watt to Dr Shore and Dr McNickle, 8 May 1942', H1 131/45 (23441).

49. 'Letter, Cameron to Watt, 2 October 1941', H1 172/551.

50. 'Letter, N.F. Ramsay to Miss Mann Nurse Inspector' (n.d.), H1 131/45 (30312).

51. Interview with 'Marsha' (pseudonym), 13 April 2002.

52. Interview with 'Marsha' (pseudonym), 13 April 2002.

53. 'Venereal Disease Clinic Report Christchurch, September 1972', in 'Draft Agenda for the Eighth National Venereologists' Conference, 17 September 1972', Venereal disease correspondence and general matters 1970-73, CH 588 14/6.

54. Quoted in 'Letter, North Canterbury Hospital Board to Watt, 10 July 1942', H1 45/47 (20361).

55. 'The public health nurse and contact tracing in the Venereal Diseases Unit at Auckland Hospital', in 'Draft Agenda for the Eighth National Venereologists' Conference, 17 September 1972', Venereal disease correspondence and general matters 1970-3, CH 588 14/6.

56. Interview with Dr Kelvin Bremner, 8 September 2002 (part-time venereologist at the Wellington Venereal Disease Clinic, 1970-86). 
57. 'Letter, Jepson (MOH) to Dr Andrews, 10 October 1963', H1 131/45 (30312).

58. 'Napier Venereal Disease Clinic Report 1971-72', in 'Draft Agenda for the Eighth National Venereologists' Conference, 17 September 1972', Venereal disease correspondence and general matters 1970-3, CH 588 14/6. Interview with 'Marsha' (pseudonym), 13 April 2002.

59. 'Marsha' (pseudonym), written correspondence with the author, 25 May 2006.

60. Interview with 'Marsha' (pseudonym), 13 April 2002.

61. Interview with Dr Kelvin Bremner, 8 September 2002.

62. 'Marsha' (pseudonym), written correspondence with the author, 16 May 2006.

\section{References}

Alexander, R.M. (1995). The 'girl problem': Female sexual delinquency in New York, 1900-1930. Ithaca, NY: Cornell University Press.

Alonzo, A.A. and Reynolds, N.R. (1995). Stigma, HIV and AIDS: An exploration and elaboration of a stigma trajectory. Social Science and Medicine, 41(3), 303-15.

Appendices to the Journal of the House of Representatives (AJHR). (1945). $\mathrm{H}-31,3$.

Baker, J.V.T. (1965). The New Zealanders at war: War economy. Wellington: Historical Publications Branch, Department of Internal Affairs.

Bierre, T.H. (1973). Venereal disease: Case and contact finding. New Zealand Medical Journal, 77(493), 380-4.

Black, H. and Farb, M. (1943). Prevalence and control of venereal disease with special reference to Wellington City. Preventive Medicine Dissertation, University of Otago.

Brandt, A.M. (1987). No magic bullet: A social history of venereal diseases in the United States since 1880. New York \& Oxford: Oxford University Press.

Bryder, L. (1991). 'If preventable, why not prevented?': The New Zealand response to tuberculosis 1901-1940. In L. Bryder (Ed.), A healthy country: Essays on the social history of medicine in New Zealand, pp. 109-27. Wellington: Bridget Williams Books.

Bryder, L. (2003). A voice for mothers: The Plunket Society and infant welfare, 1907-2000. Auckland: Auckland University Press.

Bulbeck, C. (1997). Living feminism. Cambridge: Cambridge University Press.

Coney, S. (1986). Every girl: A social history of women and the YWCA in Auckland 1885-1985. Auckland: Auckland YWCA.

Dallas, B.M. and Rainey, H.B. (1948). The control of venereal disease: With particular reference to the legislation and public health measure. Preventive Medicine Dissertation, University of Otago.

Davidson, R. (1996). Searching for Mary, Glasgow: Contact tracing for sexually transmitted diseases in twentieth-century Scotland. Social History of Medicine, 9(2), 195-214.

Davidson, R. (2000). Dangerous liaisons: A social history of venereal diseases in twentieth-century Scotland. Amsterdam \& Atlanta, GA: Rodopi.

Davies, K. (2001). Silent and censured travellers? Patients' narratives and patients' voices: Perspectives on the history of mental illness since 1948. Social History of Medicine, 14(2), 267-92.

Dow, D. (1995). Safeguarding the public health: A history of the New Zealand Department of Health. Wellington: Victoria University Press. 
Durham, J.D. (1994). The changing AIDS/HIV epidemic. Nursing Clinics of North America, 29, 9-18.

Dux, M. (2001). Relocating protest: The United Associations of Women, venereal disease and the national security regulations. Limina, 7, 47-64.

Evans, D. (2001). STD policy in the English National Health Service, 1948-2000. In R. Davidson and L. Hall (Eds.), Sex, sin and suffering: Venereal disease and European Society since 1870, pp. 237-53. London \& New York: Routledge.

Fairchild, A.L., Colgrove, J. and Bayer, R. (2003). The myth of exceptionalism: The history of venereal disease reporting in the twentieth century. Journal of Law, Medicine \& Ethics, 31(4), 624-37.

Fleming, P. (1989). Shadow over New Zealand: The response to venereal disease in New Zealand 1910-1945. PhD thesis, Massey University.

Geiger, S. (1992). What's so feminist about doing women's oral history? In C. Johnson-Odim and M. Strobel (Eds.), Expanding the boundaries of women's history, pp. 305-18. Bloomington \& Indianapolis, IN: Indiana University Press.

Gilman, S.L. (1988). Disease and representation: Images of illness from madness to AIDS. Ithaca, NY: Cornell University Press.

Goffman, E. (1990). Stigma: Notes on the management of a spoiled identity, 3rd reprint. London: Penguin Books.

Hall, L. (2000). Sex, gender and social change in Britain since 1880. Basingstoke: Macmillan, New York: St Martin's Press.

Hall, L. (2001). Venereal diseases and society in Britain, from the Contagious Diseases Acts to the National Health Service. In R. Davidson and L. Hall (Eds.), Sex, sin and suffering: Venereal disease and European Society since 1870, pp. 120-37. London \& New York: Routledge.

Jarvis, C.S. (2004). The male body at war: American masculinity during World War II. DeKalb: Northern Illinois University Press.

Kampf, A. (2007). Mapping out the venereal wilderness: Public health and STD in New Zealand, 1920-1980. Berlin: LITVerlag.

Kunzel, R.G. (1993). Fallen women, problem girls: Unmarried mothers and the professionalization of social work, 1890-1945. New Haven, CT: Yale University Press.

Lemar, S. (2001). Control, compulsion and controversy: Venereal diseases in Adelaide and Edinburgh 1910-1947. PhD thesis, University of Adelaide.

Lewis, M. (1997). Sexually transmitted diseases in Australia from the late eighteenth to the late twentieth century. In M. Lewis, S. Bamber and M. Waugh (Eds.), Sex, diseases, and society: A comparative history of sexually transmitted diseases and HIV/AIDS in Asia and the Pacific, pp. 249-76. Westport, CT \& London: Greenwood Press.

Link, B.G. and Phelan, J.C. (2001). Conceptualising stigma. Annual Review of Sociology, 27, 363-85.

Macnab, M. (1989). Girls of the silver dollar. In A. Rogers (Ed.), The war years: New Zealanders remember 1939-1945, pp. 29-42. Wellington: Platform.

Martyn, A. (1942). Venereal disease in New Zealand. In Progressive Publishing Society (Ed.), Shadow over New Zealand: Venereal disease, pp. 24-8.

Christchurch: Progressive Publishing Society.

Mercer, J.O. (1941). Active syphilis in New Zealand. New Zealand Medical Journal, 40(220), 343-4.

Montgomerie, D. (1989). The limitations of wartime change. New Zealand Journal of History, 23(1), 68-87. 
Mooij, A. (1998). Out of otherness: Characters and narrators in the Dutch venereal disease debate 1850-1990. Amsterdam \& Atlanta, GA: Rodopi.

Morantz, R.M., Pomerleau, C.S. and Fenichel, C.H. (1985). In her own words: Oral history of women physicians. New Haven, CT \& London: Yale University Press.

Morgan, A.G. (1947). The control of venereal disease with special reference to the venereal disease clinic - Wellington. Preventive Medicine Dissertation, University of Otago.

New Zealand Gazette. (1918). Wellington: Governmental Printer.

New Zealand Statutes. (1917). Wellington: Governmental Printer.

Platts, W.M. (1964). The problem of venereal disease with an analysis of cases. New Zealand Medical Journal, 63(378), 67-83.

Porter, D. (1999). Health, civilization and the State: A history from ancient times. London \& New York: Routledge.

Singer, W. (1997). Creating histories: Oral narratives and the politics of historymaking. Delhi: Oxford University Press.

Smith, S. (1996). Neither victim nor villain: Nurse Eunice Rivers, the Tuskegee Syphilis Experiment, and public health work. Journal of Women's History, 8(1), 95-113.

Sturma, M. (1988). Public health and sexual morality: Venereal disease in WWII Australia. Signs, 13(4), 725-40.

Thin, R.N. (1984). Health advisors (contact tracers) in sexually transmitted disease. British Journal of Venereal Diseases, 60(4), 269-72.

Walkowitz, J. (1992). City of dreadful delight: Narratives of sexual danger in lateVictorian London. London: Virago Press.

White, G. and Mortensen, A. (2003). Counteracting stigma in sexual health care settings. Internet Journal of Advanced Nursing Practice, 6(1). Available at http:// www.ispub.com/ostia/index.php?xmlFilePath=journals/ijanp/vol6n1/stigma.xml

Wollacott, A. (1994). 'Khaki Fever' and its control: Gender, class, age and sexual morality on the British Homefront in the First World War. Journal of Contemporary History, 29(2), 325-47.

\section{Author biography}

ANTJE KAMPF (b. 1970) received her PhD in history from the University of Auckland, New Zealand, funded by a Top Achiever Doctoral Scholarship from the New Zealand Ministry of Education. From 2005 she has been with the Institute for the History, Philosophy and Ethics of Medicine at the Johannes Gutenberg-Universität Mainz, Germany; since March 2006, she has been Senior Lecturer ('Junior professor') for gender aspects. Her current research project focuses on the male reproductive body and medicine in 20th-century Germany. Her publications include Mapping out the venereal wilderness: Public health and STD in New Zealand, 1920-1980 (Berlin: LitVerlag, 2007). 